\title{
ВИКОРИСТАННЯ ТЕСТОВОГО КОНТРОЛЮ ТА ТЕСТОВИХ ЗАВДАНЬ У НАВЧАННІ ІНОЗЕМНОЇ МОВИ СТУДЕНТІВ НЕМОВНИХ ВИЩИХ НАВЧАЛЬНИХ ЗАКЛАДІВ
}

\author{
Т. В. Саварин, I. Р. Бекус
}

ДВНЗ “Тернопільський держсавний медичний університет імені І. Я. Горбачевського МОЗ Украйни”

\section{APPLICATION OF TESTS' CONTROL AND TESTS' EXERCISES IN TEACHING OF FOREIGN LANGUAGE OF STUDENTS AT NON- LINGUISTIC HIGHER EDUCATIONAL ESTABLISHMENTS}

\author{
T. V. Savaryn, I. R. Bekus \\ SHEI "Ternopil State Medical University by I. Ya. Horbachevsky of MPH of Ukraine"
}

\begin{abstract}
У статті розглянуто сутнісні характеристики тестів як ефективного засобу контролю знань студентів у процесі вивчення іноземних мов у немовних вищих навчальних закладах. Виділено основні види тестів залежно від етапу навчального процесу, на якому вони впроваджуються, та проаналізовано особливості ̈̈х застосування. Визначено переваги використання тестових завдань у навчальному процесі.
\end{abstract}

The main characteristics of tests as an effective method of control of students' knowledge in the process of foreign languages teaching at non-linguistic higher educational establishments are considered in the article.The major forms of tests are stated depending on the stage of educational process at which the tests are used. Advantages of their application in educational process are determined.

Вступ. Якісне володіння іноземними мовами є необхідною умовою для входження у відкритий інформаційний простір і суспільство, для спілкування, для полегшення процесу соціологізації в сучасному ринковому середовищі. Однією із головних задач модернізації освіти є забезпечення знань на рівні функціональної грамотності принаймні однієї іноземної мови. Протягом багатьох років навчальні програми i стандарти в галузі викладання іноземних мов зводили цей рівень тільки до володіння читанням на рівні міжнародних стандартів функціональної грамотності, при цьому значно менше уваги приділялося усному мовленню, писемному мовленню та аудіюванню. В рамках нового підходу до вивчення іноземних мов підкреслюється важливість не знань про мову, а досконале володіння мовним матеріалом, комунікативними уміннями, здатністю використовувати ці знання і уміння для вирішення конкретних комунікативних задач у ситуаціях спілкування.

Основна частина. Перехід немовних вищих навчальних закладів до системи кредитно-модульного навчання спричинив значну увагу освітян до тестів успішності як засобу оцінювання навчальних досягнень студентів. Цей інтерес $\epsilon$ цілком виправданим, () Т. В. Саварин, I. Р. Бекус оскільки тестування $є$ ефективним засобом контролю і дає можливість у досить короткий час сформувати уявлення про знання студентів. Так, тест дозволяє перевіряти одночасно всіх студентів групи; виконання тесту займає небагато часу, що робить можливим його проведення практично на будь-якому занятті; при виконанні тесту всі студенти знаходяться в рівних умовах - вони працюють в один і той же час з однаковим за обсягом та складністю матеріалом; також тест дає можливість контролювати не тільки засвоєння матеріалу, але й володіння окремими вміннями його використання. Ці характеристики тестів, безумовно, свідчать про доцільність їх використання в навчальному процесі [1].

Недостатньо вивченою $є$ на сьогодні і проблема використання тестів у немовних вищих освітніх закладах під час вивчення іноземних мов.

Метою нашого дослідження $€$ аналіз сутнісних характеристик, видів, основних переваг та недоліків тестових завдань у процесі вивчення іноземної мови в немовних вищих навчальних закладах.

Вітчизняні дослідники (О. Вакуленко, Д. Гільчук, О. Коваленко, В. Коккота, С. Ніколаєва, О. Петращук, А. Рапопорт, Н. Саєнко, Т. Товкес, О. Холод, 
Н. Чорна та ін.) присвятили дослідженню проблеми використання тестів чимало праць. Цьому питанню приділяється досить велика увага і у дослідженнях зарубіжних учених (J. Alderson, R. Arends, M. Ash, L. Bachman, M. Canale, E. Hagen, R. Ebel, E. Goetz, R. Thorndike, M. Swain, J. Heaton, H. Madsen). Cyчасні дослідники вивчають теоретичні та практичні аспекти застосування тестів, аналізують особливості організації тестового контролю тощо. Однак надмірна захопленість тестуванням у навчальному процесі без відповідного критичного осмислення різних його аспектів може привести до недостатньо об'єктивної оцінки його навчальної цінності і тим самим замість користі завдати шкоди справі практичного викладання іноземної мови [1]. Так, на заняттях латинської мови об' єктом вивчення стали не лише елементи цієї мови (фонетика, графіка, морфологія, синтакс словосполучень, лексичний і словотворчі матеріали класичних мов), але й принципи термінотворення, зокрема анатомічної, гістологічної, клінічної та фармацевтичної номенклатур, написання латинською мовою простих клінічних діагнозів. Іншими словами, чітко визначилася термінологічна спрямованість всього процесу навчання, оскільки термін посідає особливе місце на всіх етапах медичної освіти, бо виступає і як інструмент пізнання, і як словесний знак, який закріплює результат цього пізнання. Тому згідно з вимогами курсу латинської мови і основ медичної термінології є вироблення у студентів навичок грамотного використання латинської анатомічної, гістологічної, клінічної, фармацевтичної, медико-технічної термінологій, латинської хімічної номенклатури та розуміння назв лікарських препаратів і номенклатурних найменувань, уміння написати латинську частину рецепта, перекласти латинською мовою клінічний діагноз в обсязі загальноприйнятої традиції. Щоб орієнтуватися в цій величезній за кількістю латинській термінології, розуміти значення окремих термінів і словосполучень, студенти повинні вивчити правила латинської граматики, ії закономірності та винятки 3 правил, способи термінотворення, принципи перекладу двослівних і багатослівних термінів і клінічних діагнозів тощо. Для досягнення цієї мети викладачі латинської мови використовують не тільки тестовий контроль, але й письмовий, який більш ефективно допомагає перевірити вміння студентів написати той чи інший діагноз, рецепт тощо.

Отож, для діагностики успішності навчання використовуються різноманітні форми, методи та прийоми контролю. Найпоширенішою формою контролю в галузі викладання іноземної мови на сьогодні є те- стовий контроль. Тестування широко застосовується на всіх ланках навчання, починаючи з тренувального контролю і закінчуючи самопідготовкою.

Тести успішності повинні відповідати ряду вимог. Вони повинні бути: відносно короткотерміновими, тобто не вимагати значних затрат часу; однозначними, тобто не допускати вільного тлумачення тестового завдання; правильними, тобто виключати можливість формулювання багатозначних відповідей; бути відносно короткими; зручними, тобто придатними для швидкої математичної обробки результатів; стандартними, тобто придатними для широкого практичного використання [4].

Розрізняють нормативно-орієнтовані і критеріально-оріснтовані тести [5].

Залежно від етапу дидактичного процесу, на якому використовуються тести, за їх допомогою ефективно забезпечується попередній, поточний, тематичний i підсумковий контроль знань та вмінь студентів [4].

Основними показниками, що характеризують тест, $\epsilon$ валідність і надійність. Валідність - показник того, що тест справді оцінює знання і вміння, для перевірки яких він призначений. Якщо експерти згодні 3 тим, що тест добре оцінює знання й уміння з певної теми, для якої він створений, то його можна вважати валідним. Надійність - показник точності та стійкості результатів тесту при його багаторазовому застосуванні. Він означає ймовірність одержання студентами однакових результатів за виконання тесту в різноманітних ситуаціях тестування, зокрема при оцінюванні різними експертами. Тест вважають надійним, якщо різні педагоги однаково оцінюють його виконання студентом [5].

Дещо складнішою є ситуація із "мовленнєвими" тестами, розробка яких почалася не так давно. Складність проблеми зумовлюється тим, що досі залишається в принципі незрозумілим, яким чином за допомогою тесту перевіряти рівень володіння тим чи іншим видом мовленнєвої діяльності. Тут є два підходи, згідно з якими володіння тим чи іншим видом мовленнєвої діяльності встановлюється опосередковано шляхом оцінки мовленнєвої поведінки в процесі виконання самої мовленнєвої діяльності та безпосередньо через перевірку володіння студентами певним мовним матеріалом (для чого використовуються “мовні”, тести) чи якими-небудь іншими видами мовленнєвої діяльності [1].

Таким чином, тестування має цілий ряд переваг: можливість охопити велику кількість студентів (всю групу або курс), використовуючи однаковий матеріал і однакові умови процедури тестування; економія 
аудиторного часу, що дуже важливо в немовних ВНЗ, де час на вивчення мови лімітований; зорієнтованість на сучасні технічні засоби навчання та використання комп'ютерних навчальних та контролюючих систем; збільшення об'єктивності педагогічного контролю, мінімізація суб' єктивного фактора під час оцінювання відповідей [6].

Гнучкість та універсальність сучасних комп'ютерів, здатність вилучати, відшуковувати, зберігати та надавати 3 надзвичайно великою швидкістю та у надзвичайно короткий термін будь-яку за виглядом та змістом інформацію давно поставили питання про можливість його використання при вивченні іноземних мов.

На сучасному етапі доцільно проводити тестування $з$ використанням комп’ютерної техніки. Комп’ютерне тестування відіграє важливу роль у контролі знань з іноземної мови і тому викликає до себе особливий інтерес. Тести почали застосовувати декілька десятиліть тому. I лише в останні роки комп'ютерні тести упроваджуються в масову практику й офіційно рекомендуються програмами вивчення різних іноземних мов. Проте проблема комп'ютерного тестування з іноземних мов ще вивчена недостатньо. Фактично відсутні серйозні публікації з цього питання як зарубіжних, так і вітчизняних авторів. Як зазначають дослідники, небезпека мовного тестування полягає в тому, що будь-яка необгрунтованість, необережність або поспішність у висновках може привести до неправильних рекомендацій, непередбачених результатів і сумнівних педагогічних наслідків [7]. У цьому плані комп'ютерний тест неминуче стає інструментом не лише оцінки якості навчання, але і ефективним засобом впливу на зміст навчання, джерелом суджень про учня і викладача.

П. К. Бабінська виділяє наступні методичні рекомендації щодо складання тестів:

1. Визначте цілі і функції тесту, що складається, тобто чи призначений він для поточного, тематичного, періодичного або підсумкового контролю.

2. Проаналізуйте об'єкти тестування і визначте навики і уміння, які підлягають контролю.

3. Проаналізуйте навчальний матеріал і визначте характер тесту.

4. Відберіть мовний матеріал, який буде використано в тестових завданнях.

5. Проаналізуйте типові помилки тих, хто навчається, і відберіть найбільш типові випадки для використання як альтернативні варіанти.

6. Визначте вигляд і обсяг тесту. Майте на увазі, що обсяг тесту залежить від відведеного часу, етапу і самого матеріалу. Підсумковий тест може вико- нуватися 10-30 хвилин. Передбачається рівна кількість завдань (наприклад, 20, 50, 100 і так далі) для зручності підрахунку балів.

7. Складіть тестові завдання. Пам'ятайте, що кожне тестове завдання містить інформаційну частину (це може бути або речення або невеликий текст), яку необхідно пропрацювати, і оперативну частину, що включає питання або завдання.

При цьому необхідно враховувати наступні основні вимоги, що пред'являються до комп'ютерних тестових завдань:

а) відповідність форми і характеру завдань тесту цілям і об'єктам тестування, а також пройденому мовному матеріалу, для забезпечення максимально можливої валідності тесту;

б) доступність за формою, змістом і рівнем складності завдань для даного контингенту тестованих;

в) дотримання принципу однієї складності;

г) врахування оптимальної середньої довжини речень (7 \pm 2 слова без пропусків) в основі тестового завдання [2].

8. Складіть альтернативи. При їх відборі необхідно, щоб всі відволікаючі варіанти іправильна відповідь містили одну і ту ж частину мови. Скористайтеся наступною типологією альтернатив в порядку їх ефективності: 1) контекстуальна відволікаюча; 2) антонім правильної відповіді; 3) неправильний синонім; 4) афіксальна відволікаюча (до правильної відповіді доданий або віднятий префікс або суфікс); 5) фонетико-графічна відволікаюча, така, що інтерферує 3 рідною мовою; 6) графічна (одна-дві букви додані до правильної відповіді або забрані від неї); 7) синтактико-семантична відволікаюча; 8) випадкове слово.

9. Простежте за тим, щоб тестові завдання були розташовані так, щоб перші 20 \% завдань були найлегшими, подальші $70 \%$ - середньої складності і завершальні $10 \%$ - ускладненими.

10. Ще раз прогляньте складений вами тест і при необхідності внесіть корективи [6].

Варто наголосити на тому, що тестові завдання дозволяють перевірити лише обмежену частину знань і не можуть повністю замінити інші форми перевірки, хоча вони відкривають багато нових можливостей перед викладачем.

Висновок. Таким чином, використання тестів у процесі викладання іноземної мови у немовних вищих навчальних закладах $є$ цілком доцільним і необхідним. Проте варто зазначити, що викладачі повинні розробляти тести залежно від того, на якому етапі вивчення іноземної мови вони використовуються, їх навчальної мети, потрібно також оцінювати, 
наскільки тести вдосконалюють мовну підготовку студентів та наскільки об'єктивно вони оцінюють рівень розвитку знань, умінь та навичок студентів. Подальшого дослідження потребують аспекти, які

\section{Література}

1. Якубовська Л. П. Використання тестів у навчанні іноземної мови курсантів / Л. П. Якубовська // Наукові записки Вінницького державного педагогічного університету імені М. Коцюбинського. Серія : Педагогіка і психологія. Вінниця, 2004. - Вип. 10.-С. 192-196.

2. Чорна Н. В. Сутнісні ознаки тестів успішності в педагогіці США / Н. В. Чорна // Наукові записки Вінницького державного педагогічного університету імені М. Коцюбинського. Серія : Педагогіка і психологія. -Вінниця, 2002. -Вип. 7. - С. 75-80.

3. Психология : словарь / под ред. В. П. Зинченко, Б. Г. Мещерякова. - [2-е изд., перераб. и дополн.]. - М. : Педагогика-Пресс, 1996.-440 c. пов'язані із визначенням вимог щодо розробки тестів, з'ясування їх структури та можливих форм залежно від виду діяльності, на перевірку якого вони спрямовані.

4. Мойсеюк Н. Є. Педагогіка : навчальний посібник / Н. С. Мойсеюк. -К., 1999.-350 с.

5. Галузяк В. М. Педагогіка / В. М. Галузяк, М. І. Сметанський , В. І. Шахов. - Вінниця : Логос, 2000. - 200 с.

6. Коккота В. А. Лингво-дидактическое тестирование / В. А. Коккота.-М. : Высшая школа,1989.-117 с.

7. Окулічева Н. А. Тестовий контроль знань учнів / Н. А. Окулічева // Англійська мова та література. - 2007. № 11 (165).-Квітень. -С. 28-29.

8. Биконя О. П. Використання текстового процесора у навчанні ділової англійської мови / О. П. Биконя // Іноземні мови. -2007 . - № 1.-С. 33-38. 